\section{Relationship between spiritual quotient and self-adjustment of students at Jabal Nor Islamic Boarding School, Sidoarjo, Indonesia}

\author{
Khamida, Rizqy Mubarak, \\ Syiddatul Budury
}

Nursing and Midwifery Faculty, Universitas Nahdlatul Ulama Surabaya, Indonesia

\begin{abstract}
Adjusting to a life at Islamic boarding schools can be a very unique experience, many students are struggling and trying to cope with this new situation. The purpose of this research was to determine the correlation between spiritual quotient and the adjustment of student at Islamic Boarding School. The analysis method involved a cross sectional approach, with a population size was 60 students of class VII, who live in boarding school. Furthermore, a large sample size of 53 people was selected; using simple random technique, with the independent variable being spiritual quotient and the dependent was self-adjustment. Data analysis used a Chi-Square test, where hipotesis $\mathrm{H} 1$ is accepted if $\rho<\alpha=$ 0.05 . The results showed that all respondents, who had low spiritual quotient, possessed a negative self-adjustment compared with other respondents. Chi-Square statistical test results, with a significant level $\alpha=$ 0.05 obtained the value of $\rho(0.000)$, indicating a relationship between spiritual quotient and adjustment. In conclusion, a better spiritual quotient possessed by student, affects the process of adjustment.
\end{abstract}

\section{Introduction}

Every individual has their own way to solve problems faced in life, which are often caused by numerous conditions, within or outside. The process of adaptation to a new environment could not be ranked as being good or bad, however, the process could be addressed as a collaboration of mental responses and their acts, which triggers them to solve stressors, frustration and conflicts in their mind. Furthermore, this progression is needed by everyone who just entered new surroundings, one of which is the Islamic boarding school.

Based on the statement of the caretaker at Jabal Noer Islamic Boarding School Geluran Sub District, the atmosphere does- n't mean everything is okay because often time, the students meet obstacles on their way to adaptation, simply because they were forced to be admitted into the boarding institute. Furthermore, there are lots of things to be done and it is something really different from their habit, which becomes their main problem, as a new life forces them to be independent and far away from their parent and status. Students of Islamic boarding school, have to do a quick adaptation, reach some achievements and have a broadened knowledge about the spiritual part of the religion. The problems faced could come from the physical new environment and the social life, recent obligations and also different cultures. Furthermore, the institution students are forced to be able to act exactly like their religious task, bounded by their spiritual experience and any other mechanism, as a complement to reach the happiness of life.

From the department of Research and Development, Ministry of Religion Indonesia, it was reported that the 25,000 Islamic boarding schools in the 34 provinces in Indonesia, holds 3.65 million students. ${ }^{1}$ Furthermore, the report of Indonesian Religion Department (2017), stated that the amount of this institution of learning, surmounted to 28,691 , with 4,028,660 students, of which, 2,060,029 of them are males and 1,968,631 are females. In East Java alone, there are 6,017 Islamic boarding schools, with 455,807 females and 511,149 males, while data collected with the first survey on 27th January 2018 at Jabal Noer Islamic Boarding School, Geluran Sub District of Sidoarjo, illustrated the total number of students was 224, 109 and 115 of them were males and females respectively. On the 27th January, 2018, according to the interview with 10 students, 6 of which were new students, it was mentioned that they rarely join activities, often came out from the class before the time is over, had problems following the new rules, really wanted to return home because of lack of comfort and a fully booked schedule and also they were forbidden to bring with them a hand phone to school. Furthermore, 4 students said that they have no problem in Islamic boarding school and that they could join all activities, though a persuasive effort was first required from the caretaker.

The adaptation itself is affected by a few factors, including, physical condition, because a good body system supports good adaptation too, therefore, if there is a disability or chronic disease, it becomes the background of the obstacle itself. Furthermore, the pattern of adjustment in every person is different, in a line with the inherent mental growth, including retreat-
Correspondence: Khamida, Nursing and Midwifery Faculty, Universitas Nahdlatul Ulama Surabaya, SMEA Street 57, Surabaya, Jawa Timur 60243, Indonesia.

Tel.: +62.31.8291920 - Fax: +62.31.8298582

E-mail:khamida@unusa.ac.id

Key words: Spiritual Quotient, self adjustment, student.

Acknowledgements: The authors would like to appreciate respondents who were very cooperative and also Jabal Nor Islamic Boarding School principal and commission on board, for providing us with all facility that were required. Furthermore, we also express gratitude to the Universitas Nahdlatul Ulama Surabaya, for supporting us.

Contributions: the authors contributed equally

Conflict of interests: The authors declare no potential conflict of interest.

Funding: This project was supported by Universitas Nahdlatul Ulama Surabaya

Conference presentation: part of this paper was presented at the $3^{\text {rd }}$ International Symposium of Public Health, 2018 October 31 - November 1, Universitas Airlangga, Surabaya, Indonesia.

Dedication: This study is dedicated to all of Student Islamic Boarding School in Indonesia, and also to nursing science all over the world.

Received for publication: 28 July 2019

Revision received: 9 September 2019.

Accepted for publication: 15 October 2019.

This work is licensed under a Creative Commons Attribution NonCommercial 4.0 License (CC BY-NC 4.0).

C Copyright: the Author(s), 2019

Licensee PAGEPress, Italy

Journal of Public Health in Africa 2019; 10(s1):1184 doi:10.4081/jphia.2019.1184

ing from childish ways, to respond to the environment. However, this is not only a learning process because it's simply a function of the individual becoming more mature than before. ${ }^{1}$

Grade of religion and religious culture are another factor that contributed to reduce stressful, conflict, frustration and any other psychologist pressure because being religious, by virtue of an enhanced spirituality, gives a value and belief, where the individual has worth, aim and stability to face the pressure and change in their life. Furthermore, the quotient in their spiritual side thus builds their character and strength, during the process, hence, with an upgrade 
in spirituality, an individual adjusts into new surroundings and however, culture in a society is also a factor that can build someone who finds it hard to adapt characters and behaviors. ${ }^{2}$

Efforts to solve the problem of selfadjustment requires that they were expected to possess a good spiritual quotient, with indicators that students partake in activities and regulations, previously determined, without encouragement from others and also solve problems, with positive thinking and that they are not in a hurry to make decision. Furthermore, in accordance with the above indicators, a good personality is also perceived of them, supported by the boarding school environment and the role of mentors or caregivers. In the Islamic boarding school, students are educated and accustomed to activities, including discipline, crafts, courtesy, hospitality and others. Furthermore, the spirit of learning also needs to be possessed hence, what is aimed at is included in the program, which includes having sound knowledge that can later be applied, individually and to the society in everyday life.

The purpose of this research was therefore to determine the correlation between spiritual quotient and self-adjustment of students at Jabal Noer Islamic boarding school Geluran, Sub District of Sidoarjo.

\section{Materials and Methods}

The type and design of this research, used analytic and cross sectional approach, where the sample were students, who lived at the institutions boarding facility, consisting of 53 people, taken using simple random sampling technique. Furthermore, the independent variable was spiritual quotient, measured with The Spiritual Quotient Self-Report Inventory (SISRI) questionnaire, while the dependent was self-adjustment and the instrument used to measure this was a modified questionnaire based on the self-characteristics of Schneiders adolescents ${ }^{3}$ and data was further analyzed, using Chi Square test.

\section{Results}

The results showed characteristics of respondents, based on spiritual quotient, self-adjustment and cross tabulation between spiritual quotient and selfadjustment.

Characteristics of respondents, based on spiritual quotient and self-adjustment are analyzed in Tables 1 and 2. Distribution of the relationship of spiritual quotient to self- adjustment is represented in Table 3. Chi Square statistical test results, obtained a $\mathrm{p}$ value $=(0.000)<\alpha(0.05)$, indicating that $\mathrm{H}_{0}$ is rejected, thus there exists an $\alpha$ relationship between spiritual quotient and students' self-adjustment at Jabal Noer Islamic Boarding School in Sidoarjo.

\section{Discussion}

The results on the independent variables obtained, showed that most $(50.9 \%)$ or 27 students possess moderate spiritual quotient (22-62), which is the ability to attribute meaning to worship in every behavior and activity, through steps, integralistic thinking and principles, only because of God. Furthermore, its development is defined as trust in the power of the divine, as the expression of this belief is used to feel love and trust in God. ${ }^{4}$

Based on the spiritual quotient questionnaire, almost all (78\%) students realize that patience is very important as they believed that it could solve everything properly, with a positive mindset. Furthermore, students were also taught to practice the religious values taught during the boarding school, especially about the meaning of patience and spiritual quotient, among others, is capable of attributing meaning to worship, in every behavior and activity, through steps, integralistic thinking and principles, for Gods' sake, ${ }^{4}$ therefore influenced by several factors, including brain nerve cells, age and god points. ${ }^{5}$

Regarding prayer, most (67\%) students believed that praying enhances closeness to God, indicating that they do not fully believe in the power of prayer and the true meaning of religion, which has an important influence on spiritual quotient. However, a person with elevated independent variable grows in the belief that there is a power that comes from God, awareness of his existence and also, a clear goal of being his servant and a leader on earth. ${ }^{6}$ Therefore, the individuals who have high spiritual quotient are able to more easily accept and allot meaning to everything that happens.

In the first sacred proportion sub variable, regarding the ability to think spiritually, the majority $(52.8 \%)$ of respondents, help people who ask for it, however, the second, is the ability to find and create meaning, where most $(60.4 \%)$ student state that praying enhances the

Table 1. Frequency distribution of respondents, based on spiritual quotient in seventh graders at Jabal Noer Islamic Boarding School Sidoarjo.

\begin{tabular}{llcc} 
No & Spiritual Quotient & Frequency & Percentage (\%) \\
1. & Low & 0 & 0 \\
2. & Middle & 27 & 50.9 \\
\hline 3. & High & 26 & 49.1 \\
& Total & 53 & 100 \\
\hline
\end{tabular}

Resource: Primary Data, July 2018.

Table 2. Frequency distribution of respondents based on self adjusment in seventh graders at Jabal Noer Islamic Boarding School Sidoarjo

\begin{tabular}{llcc} 
No & Self Adjusment & Frequency & Percentage (\%) \\
1. & Negative & 27 & 50.9 \\
2. & Positive & 26 & 49.1 \\
\hline & Total & 53 & 100 \\
\hline
\end{tabular}

Resource: Primary Data, July 2018.

Table 3. Cross tabulation between spiritual quotient and adjustment of students, at Jabal Noer Islamic Boarding School in Sidoarjo.

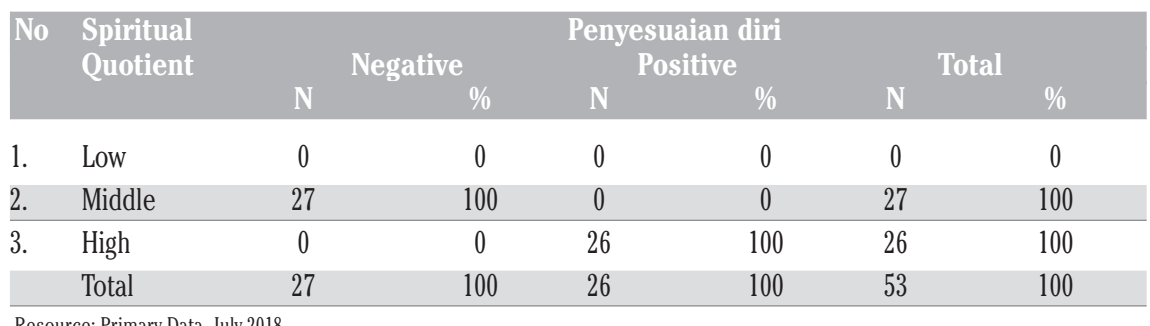

Resource: Primary Data, July 2018. 
feeling of closeness to God, Furthermore, the third is the talent to explore spiritual aspects, in which most $(62.3 \%)$ of student always respect people with different opinions, and the fourth is about the aptitude to develop spiritual aspects in part as a large $(58.5 \%)$ proportion, always try to do good to themselves and others around them. From the results on the level of selfadjustment of student at Jabal Noer Sidoarjo Islamic boarding school, it was observed that of the 53 respondents, most $(50.9 \%)$ or 27 students had negative selfadjustment, which was propably due to level of education and age (12-15 years old), as they were all included in the early adolescence category. Furthermore, during this phase, they did not fully have strong self-confidence, when interacting and mingling with the surrounding environment, which could lead to lack of experience obtained, through social interaction in society. Self-adjustment is however considered successful, if someone has a realistic life, good social relationship, stable emotional level and a strong selfconcept in their life. 7

Education also influences adjustment as all 53 respondents, have basic education (elementary-junior high school), who have limited knowledge on interacting with the environment because they potentially feel bored, joining up on activities and learning processes. Furthermore, the ability to learn is an important element in the formation of a positive self-adjustment because the responses and personality traits, generally needed are obtained through the learning process both by school and society. ${ }^{8}$

Adaptation is an essential point for human life, which identifies the numerous characteristics that shapen a person's personality. Self-adjustment is a situation where the individual is very happy and satisfied with all aspects of personal life, thus achieving a good correlation with the environment and happiness to witness its survival. Furthermore, it cannot be judged as good or bad, however, in simpl terms, it can be interpreted as a process that involves mental responses and behaviors, which cause a trial to overcome the tensions, frustration and inner conflicts that occur to the individual due to the interaction with the environment and one another.

The results of self-adjustment questionnaire, shows that almost all (87\%) students asked others who have better knowledge, in cases of inability to complete the tasks of the pesantren, as everyone has a personalized method of solving problems. Furthermore, most (67\%) students feel bored quickly, which is also a personality problem, besides that, the environment plays an important role in the adjustment process. It is therefore implied that the process of self-adjustment is very dependent on the psychological aspects (psychic) of a person, in relation to properties and materials, as well as on the feelings of soul or mind. Furthermore, at deprived life levels, a happy heart fosters the feeling of contentment and comfort. This further indicates a proper adjustment, to nature, the surrounding environment and most importantly to the supernatural (God). This analogy is however reinforced by the opinion of Schneider, who stated that selfadjustment is eaten as adaptation, conformity (equality) and individual variation and also as completeness. ${ }^{9}$

The Chi Square statistical test, obtained a $\mathrm{p}$ value $=(0.000)<\mathrm{a}(0.05)$, indicating that $\mathrm{HO}$ is rejected, hence there is a significant correlation between spiritual quotient and self-adjustment in seventh grade students at Jabal Noer Islamic Boarding School Sidoarjo. The result of cross tabulation in Table 3, obtained from 27 students, who have moderate spiritual quotient, where all $(100 \%)$ had negative self-adjustments and 26 respondents, with high spiritual quotient all $(100 \%)$ possessed a positive adjustment, showing that this independent variable plays an important role in adjusting to the environment. A teenager with a good spiritual life (always involves the values of Religion in any case, controls emotions with a positive mind) were better able to adapt well, are found at the right time and at the right time. Furthermore, if teenagers have stable emotions, they are capable of adjusting to desired expectations, with the facts that exist, hence they face problems calmly and spiritual quotient can also be seen or measured from the emotional maturity of students in dealing with problems faced in their environment.

Not all teenagers are able to change accordingly, which is mainly associated with the development of adventurous adolescents, here conflicts with parents in particular have been recorded and they prefer to perform activities with friends with abiding by rules. In this research, respondents were seventh grade students, living in Islamic boarding schools, where some had first settled in a boarding facility after graduating from elementary school.

Self-adjustment is a process that includes mental responses and behavior, which involves an individual's effort to achieve success, in linking needs, overcoming tension, conflict and frustrations experienced as an individual. ${ }^{9}$ Furthermore, spiritual quotient impacts the greatest influence on self-adjustment because there is a factor called the God Spot, which serves as a belief in the existence of the power of the almighty and thus determine the purpose of life in each individual. Therefore, a person who has an elevated level of emotions and a high divine quotient is a real clue to achieving life success and overall adaptation because of its relationship with self-adjustment, which is an important part of the process.

\section{Conclusions}

In conclusion, there is a correlation between spiritual quotient and self-adjusment at Jabal Noer Islamic boarding school Sidoarjo. Therefore, it is expected that all teachers or caregivers, administer a direct punishment to those who disobey the rules and also appropriate an extra attention to those who are rarely active, while interacting with friends or others. Furthermore, mentors should motivate their student to enhance adaptation with the new environment.

\section{References}

1. Kementerian Agama Republik Indonesia. Analisis dan Interpretasi Data pada Pondok Pesantren, Madrasah Diniyah (Madin), Taman Pendidikan Qur'an(TPQ) Tahun Pelajaran 20112012. Available from: http://pendis.kemenag.go.id/file/dokumen/pontrenanalisis.pdf: 2012. Accessed on: 13 August 2018.

2. Ula FM. Hubungan Antara SelfEfficacy dengan Penyesuaian Diri Pada Student SMP, (tidak diterbitkan). Surabaya: Fakultas Keperawatan dan Kebidanan UNUSA; 2016.

3. Ariyanti. Hubungan Frekuensi Kunjungan Keluarga dan Kecerdasan Emosional dengan Penyesuaian Diri Student baru di Pondok Pesantren Darul Muttaqien Bogor. Available from: http://repository.uinsyarifhidayatullah.a c.id: 2014. Accessed on: 13 August 2018.

4. Wilcox L. Psikologi Kepribadian. Yogyakarta: PT. IRCiSoD; 2012.

5. Zohar D, Marshall I. SQ: Kecerdasan Spiritual. Bandung: PT Mizan Pustaka; 2008.

6. Sari I. Hubungan Kecerdasan Spiritual Dengan Penyesuaian Diri Pada Siswa Yang Tinggal Di Asrama Pelajar SMA IT NUR HIDAYAH. Available from: http://eprints.ums.ac.id/56938/17/NAS KAH\%20PUBLIKASI.pdf : 2017. Accessed on: 13 August 2018. 
7. Ida ART, Putu NW. Hubungan Antara Dukungan Sosial Dengan Penyesuaian Diri Pada Remaja Awal Di Panti Asuhan Kota Denpasar. Jurnal Psikologi Udayana 2016;3:542-550.
8. Mediana W. Penyesuaian Diri Remaja yang Tinggal di Pondok Pesanten Nurul Izzah Gresik. Jurnal Psikologi Kepribadian dan Sosial 2013;2(3): 134143.
9. Agustiani H. Psikologi Perkembangan. Bandung. PT. Refika Aditama; 2009. 